\title{
ASSESSING COLLUSION RISKS IN MANAGING CONSTRUCTION PROJECTS USING ARTIFICIAL NEURAL NETWORK
}

\author{
Ming SHAN ${ }^{1}$, Yun LE ${ }^{2}$, Kenneth T. W. YIU ${ }^{3}$, \\ Albert P. C. $\mathrm{CHAN}^{4}$, Yi $\mathrm{HU}^{2 *}$, You $\mathrm{ZHOU}^{4}$ \\ ${ }^{1}$ School of Civil Engineering, Central South University, \\ Changsha, China \\ ${ }^{2}$ School of Economics and Management, Tongji University, \\ Shanghai, China \\ ${ }^{3}$ Department of Civil and Environmental Engineering, \\ The University of Auckland, Auckland, New Zealand \\ ${ }^{4}$ Department of Building and Real Estate, The Hong Kong Polytechnic University, \\ Hung Hom, Kowloon, Hong Kong
}

Received 10 March 2016; accepted 04 March 2017

\begin{abstract}
Being an insidious risk to construction projects, collusion has attracted extensive attention from numerous researchers around the world. However, little effort has ever been made to assess collusion, which is important and necessary for curbing collusion in construction projects. Specific to the context of China, this paper developed an artificial neural network model to assess collusion risk in construction projects. Based on a comprehensive literature review, a total of 22 specific collusive practices were identified first, and then refined by a two-round Delphi interview with 15 experienced experts. Subsequently, using the consolidated framework of collusive practices, a questionnaire was further developed and disseminated, which received 97 valid replies. The questionnaire data were then utilized to develop and validate the collusion risk assessment model with the facilitation of artificial neural network approach. The developed model was finally applied in a real-life metro project in which its reliability and applicability were both verified. Although the model was developed under the context of Chinese construction projects, its developing strategy can be applied in other countries, especially for those emerging economies that have a significant concern of collusion in their construction sectors, and thus contributing to the global body of knowledge of collusion.
\end{abstract}

Keywords: collusion risk, construction project, artificial neural network, China.

JEL Classification: L74, C45.

${ }^{\star}$ Corresponding author. E-mail: $y i \_h u @ t o n g j i . e d u . c n$ 


\section{Introduction}

Collusion has been defined as a set of behaviours where competitors coordinate their market behaviour surreptitiously, which is contrary to the principles of free competition (Chotibhongs, Arditi 2012a, 2012b; Zarkada-Fraser 2000). Early in the 1980s, collusion has already been recognized as a basic area that is worthy of working on (Carr, Maloney 1983). Since then, considerable efforts were devoted to this area in various countries worldwide (Le, Shan 2014), such as Australia (Ray et al. 1999; Vee, Skitmore 2003), India (Tabish, Jha 2011), South Africa (Bowen et al. 2007a, 2007b), Turkey (Gunduz, Önder 2013) and Nigeria (Alutu 2007; Alutu, Udhawuve 2009; Ameh, Odusami 2010). Collusion has sabotaged the construction industry significantly (Vee, Skitmore 2003; Shan et al. 2017). It can not only result in a decrease in bidder numbers and an increase in contract price(Ray et al. 1999; Zarkada-Fraser 2000; Ballesteros-Pérez et al. 2013), but also trigger other unethical behaviours those may lead to quality failures in construction projects (Le, Shan 2014). According to Le et al. (2014a) and Bowen et al. (2007a, 2007b), collusion has been identified as a significant form of corruption in construction projects that could be encountered in entire construction period, from project conception phase to post implementation phase.

In the past three decades, the Chinese construction sector achieved a rapid development and had become a significant section to the global construction market. However, due to the imperfect legislation and administration systems, China faces a severe challenge of coping with collusive practices in construction projects currently (Zou 2006; Le et al. 2014a; Shan et al. 2015a, 2015b). Collusive practices have spread so extensively that they have been detected from numerous construction projects, from the small ones estimating CNY 3 million (approximately USD 0.47 million) (Xinhua Net 2015), to the national-level public project such as The Three Gorges Dam (Xinhua Net 2014). According to the National Bureau of Corruption Prevention of China (2011), the number of collusion cases in the construction sector between 2007 and 2009 was 13,006, accounting for nearly 44\% of all the business bribery cases $(29,600)$ occurred in that period. These reports and statistics have indicated an urgent situation of collusion in the Chinese construction industry.

Current literature reveal that existing collusion research mainly distribute in areas such as identification of collusive practices (Ray et al. 1999; Alutu 2007; Alutu, Udhawuve 2009; Ameh, Odusami 2010; Tabish, Jha 2011), investigation of consequences of collusion (Ika 2012), exploration of factors contributing to collusion (Zarkada-Fraser 2000), detection of collusion (Chotibhongs, Arditi 2012a, 2012b; Ballesteros-Pérez et al. 2013), and collusion prevention strategies (Sichombo et al. 2009).However, little has been done on collusion assessment, which is definitely crucial for anti-collusion affairs. In addition, according to literature search, particular research on collusion in Chinese construction projects remains lacking as well. Therefore, this study aims to: (1) identify the collusive practices in Chinese construction projects, and (2) apply the identified collusive practices to advance a model to assess collusion risks in Chinese construction projects.

To achieve the aims, this study employed a combined research approach that contains both qualitative and quantitative methods, as suggested by Hon et al. (2012). First, a systematic literature review was conducted to identify collusive practices in construction proj- 
ects. Second, a two-round Delphi interview was performed to refine the identified collusive practices under the context of Chinese construction projects. Third, according to the Delphi interview results, a questionnaire was developed and disseminated among industry practitioners to collect their opinion-based data. Finally, artificial neural network (ANN) was adopted to develop the assessment model.

\section{Methodology}

\subsection{Literature review}

To identify collusive practices in construction projects, a comprehensive and systematic literature review was conducted. The targets for the literature search contained journal papers, books, reports, news and documents that have discussed the collusion issues in construction projects. Particularly, the search for journal papers followed the popular search strategy advocated by Le et al. (2014b), Yi and Chan (2014), and $\mathrm{Hu}$ et al. (2015). The journal review scope not only covered peer-reviewed journals in construction engineering and management, such as the Journal of Construction Engineering and Management, Automation in Construction, Construction Management and Economics, Building Research and Information, Journal of Management in Engineering and Building and Environment, but those in other management domains, such as the Journal of Business Ethics and Journal of Development Studies, as well. It is believed that such a comprehensive literature review can offer a solid and sufficient support for the identification of collusive practices in construction projects.

\subsection{Delphi interview}

The Delphi method is a structured communication and consensus building approach amongst a group of experts on a complex problem, which has been widely adopted in construction engineering and management research (Hallowell, Gambatese 2009; Hon et al. 2012; Xia, Chan 2012a, 2012b; Ameyaw et al. 2016). Considering that the identified collusive practices are all from literature, a two-round Delphi interview was thus conducted with Chinese industry experts to fit these collusive practices in the context of China. A total of 15 experts that possess at least ten years of experience in the Chinese construction sector and management experience related to tendering were targeted and invited to the Delphi interview. Table 1 shows the profile of the expert panel. It could be noted that all the experts possess senior positions in their institutions and have sufficient work experience. Additionally, diversified professional backgrounds (i.e. client, consultant, contractor, designer, supplier, and academia) of these experts also help raise the heterogeneity of the Delphi panel and thus enhance the quality of interview (Ameyaw et al. 2016). 
Table 1. Profile of the Delphi panel

\begin{tabular}{|c|c|c|c|c|}
\hline Expert & Employer & Position & $\begin{array}{c}\text { Years of } \\
\text { experience }\end{array}$ & $\begin{array}{l}\text { Largest project ever } \\
\text { managed/consulted }\end{array}$ \\
\hline & Client & Project Manager & 19 & US\$ 167 million \\
\hline & Client & Deputy Manager & 16 & US\$ 308 million \\
\hline & Client & Director & 15 & US\$231 million \\
\hline & Contractor & Deputy Manager & 17 & US\$ 363 million \\
\hline & Contractor & Project Manager & 25 & US\$ 122 million \\
\hline & Contractor & Project Manager & 20 & US\$ 85 million \\
\hline & Consultant & Deputy Manager & 16 & US\$ 35 million \\
\hline & Consultant & Deputy Manager & 18 & US\$ 20 million \\
\hline & Consultant & General Manager & 16 & US\$ 55 million \\
\hline & Designer & Director & 25 & US\$ 197 million \\
\hline & Designer & Project Manager & 20 & US\$ 73 million \\
\hline & Supplier & General Manager & 15 & US\$ 122 million \\
\hline & Supplier & General Manager & 17 & US\$ 167 million \\
\hline & Academia & Professor & 20 & US\$ 363 million \\
\hline & Academia & Professor & 17 & US\$ 231 million \\
\hline
\end{tabular}

In the first round Delphi interview, experts were demanded to evaluate the occurrence probability of each identified collusive practice in the context of Chinese construction projects, in accordance with a five-point rating scale (i.e. $5=$ very common, $4=$ common, $3=$ medium, 2 few, and $1=$ very few). Meanwhile, experts were also encouraged to list any new collusive practices based on their experiences. Mean value of each collusive practice was computed and then fed back to the Delphi panel.

In the second round Delphi interview, experts were requested to re-assess their evaluations in light of the results of the first round interview. A cut-off criterion of 3.0 points was adopted to trim the identified collusive practices, as recommended by Jamieson (2004). To check if significant difference exists in experts of different professional backgrounds, the Kruskal-Wallis test was conducted as recommended by Hon et al. (2012) and Ameyaw et al. (2016).

\subsection{Questionnaire}

Questionnaire is a competent tool used to gauge people's perceptions of a subject, and it has been widely used in previous collusion studies (Zarkada-Fraser 2000; Zarkada-Fraser, Skitmore 2000). Hence, this study also used the questionnaire to collect data. An anonymous online questionnaire was developed based on the Delphi interview results. To maximize the number of potential respondents for the questionnaire, a number of governmental departments, enterprises, and research institutions, were contacted. A total of 12 institutions agreed to facilitate the questionnaire, and these institutions comprise two governmental 
departments, three clients, two contractors, one construction consultants' association, two designers, one supplier, and one research institution. All of these institutions are typical and active players in the Chinese construction sector and can provide numerous qualified potential respondents for the questionnaire.

The questionnaire included three parts as follows. Part A solicited personal information from each respondent. In Part B, according to his/her experience in a typical project, the respondents were requested to assess the probability and severity of each collusive practice using a five-point rating scale (" 1 " represents for the least probability and severity, " 5 " represents for the highest probability and severity). Such a measuring approach is recommended by Shen et al. (2001), Molenaar (2005), Zou and Zhang (2009), Ke et al. (2011), Hwang and $\mathrm{Ng}$ (2015), and Hwang et al. (2016) in their risk evaluation studies which is similar to the evaluation of collusive practices in this study. In Part C, each respondent was requested to indicate a holistic perception of collusion risk to his/her project, using a scale of $0-100 \%$. The use of $0-100 \%$ scale was due to the subsequently adopted ANN activation function of logsig, for which the output ranges from 0 to 1 (Hussain et al. 2010). A series of statistical analysis techniques, including Cronbach's alpha, one-sample $t$-test, and independent samples $t$-test were also employed to test the collected data.

\subsection{Artificial Neural Network}

Artificial Neural Network is an information processing approach which imitates the nervous system of human brain, and is used to estimate or approximate unknown functions depending on diverse inputs (Samarasinghe 2007; Goh, Chua 2013). ANN has been widely adopted in construction engineering and management research. This approach has been utilized to examine topics such as construction safety (Goh, Chua 2013; Patel, Jha 2015a, 2015b; Goh, Binte Sa’Adon 2015), project success (Ko, Cheng 2007; Cheng et al. 2010; Wang, Gibson Jr. 2010; Cheng et al. 2012), performance management (Georgy et al. 2005; Cheung et al. 2006; Ko et al. 2007; Jha, Chockalingam 2011; Cheng et al. 2011), risk management (Al-Sobiei et al. 2005; Jin, Zhang 2011), project dispute resolution (Cheung et al. 2000), and organizational effectiveness (Dikmen et al. 2005). ANN has received such a wide application because it is a data-driven and self-adaptive method that is particularly suitable for real-world problem solving, especially for those of non-linear, distributed, parallel and local processing natures (Boussabaine 1996). For its various functions, ANN can be used for risk analysis, decision making, resource optimization, prediction, and classification (Moselhi et al. 1991; Boussabaine 1996; Patel, Jha 2015b). Comparing with conventional regression models, ANN has been strongly recommended for its capability of predicting outcomes more accurately (Rumelhart et al. 1994; Wang, Gibson Jr. 2010; Patel, Jha 2015b). Given collusion is a complicated topic which is full of uncertainty, ANN is an appropriate and competent method to develop a model that is dedicated for the assessment of collusion risks in construction projects.

For the network architecture of the model, this study adopted a commonly used multi-layered feed-forward network and used back-propagation algorithm to train the network, 
as suggested by Patel and Jha (2015b). Specifically, the Levenberg-Marquardt back-propagation learning algorithm was adopted for training. It was selected because it can acquire a lower mean square error (MSE) than other algorithms for function approximate problems, and can help prevent over-fitting problems (Demuth, Beale 2000; Patel, Jha 2015a, 2015b). The common used logsig function was selected as activation function (Hussain et al. 2010), and the one-hidden-layer was utilized as it is enough for assessment purposes (Zhang et al. 1998). The inputs of the model were the respondents' evaluations of collusive practices, while the outputs of the model were the respondents' perceptions of collusion risks in their evaluated projects. The training, validating, and testing of the network was conducted with the aid of MATLAB NN toolbox.

\section{Results}

\subsection{Identification of collusive practices}

A total of 20 papers those investigated collusive practices were spotted from the literature search. Additionally, two noted and useful Organization for Economic Co-operation and Development (OECD) documents, namely the Recommendation of the OECD Council on Fighting Bid Rigging in Public Procurement (OECD 2012) and Guidelines for Fighting Bid Rigging in Public Procurement (OECD 2009), were also targeted as the sources of collusive practices. After going through these journal papers and two OECD documents, 22 specific collusive practices were identified. Based on their initiators and the different project phases, the identified collusive practices were categorized into four groups, namely, client related collusive practices in bidding, contractor related collusive practices in bidding, contractor related collusive practices in project construction, and supplier related collusive practices.

Client related collusive practices in bidding. In fact, many collusive practices in project bidding phase are initiated by clients. For instance, clients may publish an inadequate advertising of tender and set very short bid periods so that only companies notified illegally have sufficient time to produce solid bids (de Jong et al. 2009). Clients may misuse prequalification requirements to preclude qualified companies from candidate lists and only allow their favoured companies to contend (Lo et al. 1999); divulge vital tender information to their preferred tenderers (Vee, Skitmore 2003; Sichombo et al. 2009); hint tenderers to inflate tender price by a pre-arranged amount in return for kickbacks (Sichombo et al. 2009; de Jong et al. 2009); and provide biased evaluations to their favoured contractors (Tabish, Jha 2011). In some extreme cases, clients pre-select companies and then call tenders to fulfil organizational or statutory requirements (Bowen et al. 2012), or even award contracts to their preferred companies illegally without an execution of a tendering procedure which iscompulsory (Alutu 2007; Alutu, Udhawuve 2009; Tabish, Jha 2011).

Contractor related collusive practices in bidding. The most common collusive practice of contractors in bidding is that contractors collude on pricing for projects, either by escalating construction costs, or by creating a situation in which contractors win contracts because of a pre-planned sequence rather than they offer the best price (Priemus 2004; 
Dorée 2004; Hartley 2009; Sichombo et al. 2009). Also, withdrawal from bidding process is a typical type of collusive practice, in which a collusive agreement is reached that the tenderer providing the most competitive price gives up the contract so that the pre-established tenderer can win the contract (Zarkada-Fraser, Skitmore 2000). Besides, an unqualified contractor may use the name of a qualified contractor to bid for projects, and this case is especially common in projects that are of small size (Lo et al. 1999). In addition, a contractor may bribe the bidding consultant to obtain vital information of its competitors (Bowen et al. 2007a), and bribe the tender evaluation panel to seek for illegal competitive advantages in bidding (Zou 2006; Tabish, Jha 2011).

Contractor related collusive practices in project construction. Contractors should be responsible for the majority of collusive practices during project construction. For example, under collusive agreements with contractors, the site supervisor might ignore the slow implementation of projects, unfulfilled contract requirements, the use of incomplete and low quality materials, and some other malpractices conducted by contractors (Alutu 2007). Having received illegal benefits from contractors, quantity surveyors may issue completion certificates falsely, even when jobs are incomplete or sometimes abandoned. The quantity surveyors might also help contractors blow the cost of construction changes; and fluctuate the prices of work items (Alutu, Udhawuve 2009; Sichombo et al. 2009; Ameh, Odusami 2010; Tabish, Jha 2011). To get extra profits from construction changes, contractors may bribe designers and ask for unnecessary design change orders (Sohail, Cavill 2008). Additionally, staff members from the client may actively approve those change orders so that he/she could expect kickbacks from the contractor (de Jong et al. 2009).

Supplier related collusive practices. Suppliers also play a shameful role in collusive practices in construction projects. A supplier may bribe the client staff to get it nominated as the supplier of the project (Bowen et al. 2007a). Suppliers can even manipulate the project design to benefit themselves. For instance, the design may be over specified to a particular supplier so that other suppliers are excluded (Bowen et al. 2007a; Ameh, Odusami 2010). In addition, the project can also be over designed to increase the collusive earnings for the engineer and supplier (Ameh, Odusami 2010). According to the collusive agreement between the supplier and contractor, those inferior construction materials may be provided and used favourably (Sichombo et al. 2009). In addition, the quantity and quality of construction materials may also be compromised due to the connivance among the client, quantity surveyor and suppliers, thus, the illegal profits incurred would be shared at an agreed percentage (Sohail, Cavill 2008; Ameh, Odusami 2010).

Table 2 shows the identified collusive practices, their definitions, categorizations, as well as their sources. These collusive practices could be regarded as indicators to collusion risks and thus could be utilized to assess collusion risks. 
Table 2. Collusive practices spotted in existing literature

\begin{tabular}{|c|c|c|c|c|}
\hline Group & No. & Collusive practice & Definition & Source \\
\hline \multirow{9}{*}{ 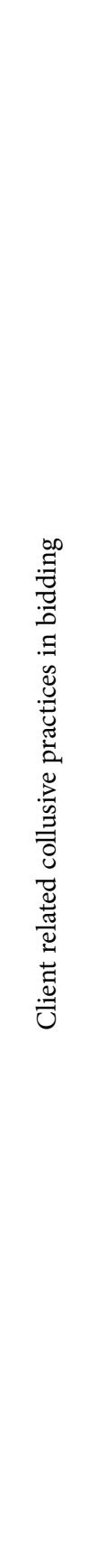 } & CP1.1 & $\begin{array}{l}\text { Misusing } \\
\text { prequalification } \\
\text { requirements }\end{array}$ & $\begin{array}{l}\text { A client misuses prequalification } \\
\text { requirements by setting up } \\
\text { the tailored prequalification } \\
\text { requirements to fit its preferred } \\
\text { tenderer. }\end{array}$ & $\begin{array}{l}\text { Lo et al. (1999), Sohail and } \\
\text { Cavill (2008), de Jong et al. } \\
\text { (2009), and Tabish and Jha } \\
\text { (2011) }\end{array}$ \\
\hline & CP1.2 & $\begin{array}{l}\text { Leaking vital } \\
\text { information } \\
\text { by the client }\end{array}$ & $\begin{array}{l}\text { A client leaks vital information } \\
\text { (e.g. pricing by other tenderers) } \\
\text { to its preferred tenderer. }\end{array}$ & $\begin{array}{l}\text { Vee and Skitmore (2003), } \\
\text { Bowen et al. (2007a and } \\
2007 \mathrm{~b}) \text {, Sichombo et al. } \\
\text { (2009), Bowen et al. (2012), } \\
\text { and Zhang et al. (2017) }\end{array}$ \\
\hline & CP1.3 & $\begin{array}{l}\text { Inflating tender } \\
\text { price }\end{array}$ & $\begin{array}{l}\text { A client hints tenderers to } \\
\text { inflate tender price in return for } \\
\text { kickbacks. }\end{array}$ & $\begin{array}{l}\text { Zarkada-Fraser and } \\
\text { Skitmore (2000), de Jong } \\
\text { et al. (2009), Sichombo } \\
\text { et al. (2009), Brown and } \\
\text { Loosemore (2015), and } \\
\text { Zhang et al. (2017) } \\
\end{array}$ \\
\hline & CP1.4 & Fake tendering & $\begin{array}{l}\text { A client pre-selects a contractor/ } \\
\text { consultant/supplier, and } \\
\text { then calls tenderers to fulfil } \\
\text { organizational or statutory } \\
\text { requirements. }\end{array}$ & $\begin{array}{l}\text { Vee and Skitmore (2003), } \\
\text { Bowen et al. (2012), and } \\
\text { Zhang et al. (2017) }\end{array}$ \\
\hline & CP1.5 & $\begin{array}{l}\text { Intervening in } \\
\text { tender evaluation }\end{array}$ & $\begin{array}{l}\text { The chief executive in a client } \\
\text { organization intervenes in } \\
\text { tender evaluation and helps his/ } \\
\text { her preferred tenderer win the } \\
\text { contract. }\end{array}$ & $\begin{array}{l}\text { Vee and Skitmore (2003), } \\
\text { Bowen et al. (2007a), } \\
\text { Tabish and Jha (2011), } \\
\text { Brown and Loosemore } \\
\text { (2015), and Zhang et al. } \\
\text { (2017) }\end{array}$ \\
\hline & CP1.6 & $\begin{array}{l}\text { Splitting a large } \\
\text { project illegally }\end{array}$ & $\begin{array}{l}\text { To evade the due tender } \\
\text { procedure, a client splits a large } \\
\text { project which should be awarded } \\
\text { by tendering into several small } \\
\text { projects and awards them } \\
\text { directly to his/her preferred } \\
\text { tenderer. }\end{array}$ & $\begin{array}{l}\text { Zou (2006), and Zhang } \\
\text { et al. (2017) }\end{array}$ \\
\hline & CP1.7 & $\begin{array}{l}\text { The lack of } \\
\text { publicity }\end{array}$ & $\begin{array}{l}\text { A client gives insufficient or } \\
\text { inadequate advertising of tender. }\end{array}$ & $\begin{array}{l}\text { Sohail and Cavill (2008), } \\
\text { de Jong et al. (2009), and } \\
\text { Tabish and Jha (2011) }\end{array}$ \\
\hline & CP1.8 & $\begin{array}{l}\text { Insufficient } \\
\text { tender time }\end{array}$ & $\begin{array}{l}\text { A client sets an excessively short } \\
\text { tender time for the potential } \\
\text { tenderers. }\end{array}$ & $\begin{array}{l}\text { Sohail and Cavill (2008), de } \\
\text { Jong et al. (2009), Tabish } \\
\text { and Jha (2011), and Zhang } \\
\text { et al. (2017) }\end{array}$ \\
\hline & CP1.9 & $\begin{array}{l}\text { The absence } \\
\text { of tender }\end{array}$ & $\begin{array}{l}\text { The chief executive in a client } \\
\text { organization approves and } \\
\text { awards a contract to his/her } \\
\text { preferred tenderer directly but } \\
\text { illegally without a necessary } \\
\text { tender procedure. }\end{array}$ & $\begin{array}{l}\text { Alutu (2007), Alutu and } \\
\text { Udhawuve (2009), Tabish } \\
\text { and Jha (2011), and Zhang } \\
\text { et al. (2017) }\end{array}$ \\
\hline
\end{tabular}


Continue of Table 2

\begin{tabular}{|c|c|c|c|c|}
\hline Group & No. & Collusive practice & Definition & Source \\
\hline \multirow{5}{*}{ 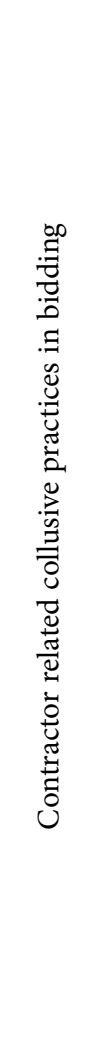 } & CP2.1 & $\begin{array}{l}\text { Bias in tender } \\
\text { evaluation }\end{array}$ & $\begin{array}{l}\text { A tenderer bribes the member(s) } \\
\text { of tender evaluation panel to } \\
\text { seek for the illegal competitive } \\
\text { advantages in tender evaluation. }\end{array}$ & $\begin{array}{l}\text { Zou (2006), Tabish and Jha } \\
\text { (2011), and Zhang et al. } \\
\text { (2017) }\end{array}$ \\
\hline & $\mathrm{CP} 2.2$ & $\begin{array}{l}\text { Misrepresentation } \\
\text { of qualification } \\
\text { certificates }\end{array}$ & $\begin{array}{l}\text { A qualified contractor facilitates } \\
\text { an unqualified contractor to } \\
\text { participate in tendering by } \\
\text { providing its qualification } \\
\text { certificate illegally. }\end{array}$ & $\begin{array}{l}\text { Bowen et al. (2007a), } \\
\text { Sichombo et al. }(2009) \text {, and } \\
\text { Bowen et al. }(2012)\end{array}$ \\
\hline & CP2.3 & $\begin{array}{l}\text { Collective } \\
\text { collusive } \\
\text { tendering by } \\
\text { helping one } \\
\text { another }\end{array}$ & $\begin{array}{l}\text { Collusive tenderers assist one of } \\
\text { them in winning the contract } \\
\text { according to an agreement that } \\
\text { they help each other win the } \\
\text { contract in turns. }\end{array}$ & $\begin{array}{l}\text { Ray et al. (1999), Zarkada- } \\
\text { Fraser and Skitmore (2000), } \\
\text { Dorée (2004), Priemus } \\
\text { (2004), Bowen et al. } \\
\text { (2007a), Hartley (2009), } \\
\text { de Jong et al. (2009), } \\
\text { Sichombo et al. (2009), } \\
\text { Ballesteros-Pérez et al. } \\
\text { (2013), OECD (2009), } \\
\text { OECD (2012), and Brown } \\
\text { and Loosemore (2015) }\end{array}$ \\
\hline & CP2.4 & $\begin{array}{l}\text { Helping the } \\
\text { pre-established } \\
\text { tenderer by } \\
\text { giving up the } \\
\text { contract }\end{array}$ & $\begin{array}{l}\text { A collusive agreement is reached } \\
\text { that the tenderer providing the } \\
\text { most competitive price helps } \\
\text { the pre-established tenderer win } \\
\text { the contract by giving up the } \\
\text { contract. }\end{array}$ & $\begin{array}{l}\text { Zarkada-Fraser and } \\
\text { Skitmore (2000), OECD } \\
\text { (2009), and OECD (2012) }\end{array}$ \\
\hline & CP2.5 & $\begin{array}{l}\text { Leaking vital } \\
\text { information } \\
\text { by the bidding } \\
\text { consultant }\end{array}$ & $\begin{array}{l}\text { A bidding consultant leaks vital } \\
\text { tendering information to the } \\
\text { particular tenderer who has paid } \\
\text { bribery. }\end{array}$ & Bowen et al. (2007a) \\
\hline 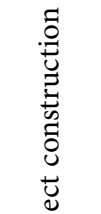 & CP3.1 & $\begin{array}{l}\text { Loose site } \\
\text { supervision }\end{array}$ & $\begin{array}{l}\text { The irregularities conducted } \\
\text { by a contractor in project } \\
\text { construction are ignored by the } \\
\text { site supervising team because of } \\
\text { the collusive pact between the } \\
\text { two parties. }\end{array}$ & $\begin{array}{l}\text { Alutu (2007), Sohail and } \\
\text { Cavill (2008), Alutu and } \\
\text { Udhawuve (2009), and } \\
\text { Wang et al. (2009) }\end{array}$ \\
\hline 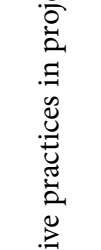 & CP3.2 & $\begin{array}{l}\text { Issuing the } \\
\text { certified works } \\
\text { falsely }\end{array}$ & $\begin{array}{l}\text { A quantity surveyor falsely } \\
\text { issues the certified works in } \\
\text { order to obtain extra money } \\
\text { from the contractor. }\end{array}$ & $\begin{array}{l}\text { Alutu (2007), Bowen et al. } \\
\text { (2007a, 2007b), Sohail } \\
\text { and Cavill (2008), Alutu } \\
\text { and Udhawuve (2009), } \\
\text { Sichombo et al. (2009), } \\
\text { Ameh and Odusami (2010), } \\
\text { and Tabish and Jha (2011) }\end{array}$ \\
\hline 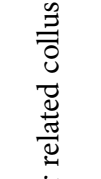 & CP3.3 & $\begin{array}{l}\text { Seeking for } \\
\text { unnecessary } \\
\text { change orders }\end{array}$ & $\begin{array}{l}\text { To get extra profits from } \\
\text { construction changes, a } \\
\text { contractor bribes the designer } \\
\text { and asks for the unnecessary } \\
\text { design change orders. }\end{array}$ & Sohail and Cavill (2008) \\
\hline 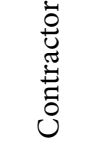 & CP3.4 & $\begin{array}{l}\text { Approval of the } \\
\text { unnecessary } \\
\text { change orders }\end{array}$ & $\begin{array}{l}\text { A contractor bribes the client } \\
\text { staff for his/her active approval } \\
\text { of the unnecessary change } \\
\text { orders. }\end{array}$ & $\begin{array}{l}\text { de Jong et al. (2009), and } \\
\text { Zhang et al. (2017) }\end{array}$ \\
\hline
\end{tabular}


End of Table 2

\begin{tabular}{|c|c|c|c|c|}
\hline Group & No. & Collusive practice & Definition & Source \\
\hline \multirow{4}{*}{ 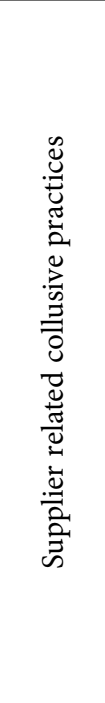 } & CP4.1 & $\begin{array}{l}\text { The nomination } \\
\text { of a particular } \\
\text { supplier }\end{array}$ & $\begin{array}{l}\text { A supplier bribes the client staff } \\
\text { to get it nominated as a supplier } \\
\text { of the project and recommended } \\
\text { to the contractor. }\end{array}$ & $\begin{array}{l}\text { Bowen et al. (2007a), and } \\
\text { Zhang et al. (2017) }\end{array}$ \\
\hline & CP4.2 & $\begin{array}{l}\text { The manipulated } \\
\text { design for } \\
\text { a particular } \\
\text { supplier }\end{array}$ & $\begin{array}{l}\text { Based on a collusive pact } \\
\text { between the designer and } \\
\text { the supplier, project design is } \\
\text { manipulated to benefit the latter. }\end{array}$ & $\begin{array}{l}\text { Bowen et al. (2007a), Sohail } \\
\text { and Cavill (2008), and } \\
\text { Ameh and Odusami (2010) }\end{array}$ \\
\hline & CP4.3 & $\begin{array}{l}\text { The usage of } \\
\text { unqualified } \\
\text { materials }\end{array}$ & $\begin{array}{l}\text { The unqualified but cheap } \\
\text { construction materials are } \\
\text { provided and used favourably } \\
\text { according to the collusive } \\
\text { agreement between the supplier } \\
\text { and the contractor. }\end{array}$ & Sichombo et al. (2009) \\
\hline & CP4.4 & $\begin{array}{l}\text { Inflating material } \\
\text { price }\end{array}$ & $\begin{array}{l}\text { The prices of the materials } \\
\text { supplied are inflated due to the } \\
\text { collusive agreement between the } \\
\text { supplier and the client/quantity } \\
\text { surveyor. }\end{array}$ & $\begin{array}{l}\text { Sohail and Cavill (2008), } \\
\text { and Ameh and Odusami } \\
(2010)\end{array}$ \\
\hline
\end{tabular}

\subsection{Delphi interview}

Table 3 shows the results of the Delphi interview. According to the feedbacks from the first round Delphi interview, no additional collusive practice was supplemented by the expert panel. Meanwhile, results from the second round Delphi interview indicated that the lack of publicity (CP1.7) and insufficient tender time (CP1.8) received evaluations below the cut-off criterion of 3.0 points, and thus were deleted from the list of collusive practices. Such results revealed that the Delphi panel considered the current publicity and tender time of most tenders in the Chinese context to be adequate. This maybe because the legislative body in China has issued The Bidding \& Tendering Law of People's Republic of China, which stipulated a series of specific and compulsory regulations on the least level of publicity and tender time (The National People's Congress of People's Republic of China 1999), and that the majority of industry practitioners followed these regulations. In addition, the KruskalWallis test result shows that the asymptotic significance value of each collusive practice is higher than 0.05 , indicating that there is no significant difference among experts of different backgrounds (Hon et al. 2012; Ameyaw et al. 2016). Thus, a total of 20 collusive practices in Chinese construction projects were finally consolidated for this study.

\subsection{Questionnaire}

A total of 108 replies were received from the questionnaire. After a careful visual examination, 11 replies were found to be inappropriately filled out, and thus were excluded. Therefore, a total of 97 valid replies were obtained. Table 4 shows respondents' backgrounds. The respondents were from diverse employers such as client, contractor, designer, consultant, 
Table 3. Results of the two-round Delphi interview

\begin{tabular}{lllll}
\hline \multirow{2}{*}{ Code } & \multicolumn{3}{c}{ First Round } & Second Round \\
\cline { 2 - 5 } & Mean & $\begin{array}{c}\text { Asymptotic Significance } \\
\text { of Kruskal-Wallis test }\end{array}$ & Mean & $\begin{array}{c}\text { Asymptotic Significance } \\
\text { of Kruskal-Wallis test }\end{array}$ \\
\hline CP1.1 & 3.94 & 0.435 & 3.96 & 0.467 \\
\hline CP1.2 & 3.73 & 0.546 & 3.70 & 0.613 \\
\hline CP1.3 & 3.44 & 0.428 & 3.38 & 0.586 \\
\hline CP1.4 & 3.33 & 0.740 & 3.28 & 0.703 \\
\hline CP1.5 & 3.28 & 0.671 & 3.21 & 0.609 \\
\hline CP1.6 & 3.15 & 0.273 & 3.11 & 0.348 \\
\hline CP1.7 & 2.78 & 0.543 & 2.76 & 0.505 \\
\hline CP1.8 & 2.25 & 0.431 & 2.20 & 0.487 \\
\hline CP1.9 & 3.54 & 0.434 & 3.51 & 0.429 \\
\hline CP2.1 & 3.18 & 0.435 & 3.14 & 0.438 \\
\hline CP2.2 & 3.89 & 0.578 & 3.90 & 0.613 \\
\hline CP2.3 & 3.68 & 0.286 & 3.64 & 0.292 \\
\hline CP2.4 & 3.16 & 0.532 & 3.11 & 0.574 \\
\hline CP2.5 & 3.80 & 0.531 & 3.82 & 0.589 \\
\hline CP3.1 & 3.92 & 0.336 & 3.93 & 0.388 \\
\hline CP3.2 & 3.63 & 0.333 & 3.56 & 0.443 \\
\hline CP3.3 & 3.50 & 0.581 & 3.44 & 0.550 \\
\hline CP3.4 & 3.69 & 0.504 & 3.62 & 0.539 \\
\hline CP4.1 & 3.32 & 0.356 & 3.29 & 0.345 \\
\hline CP4.2 & 3.43 & 0.443 & 3.41 & 0.4523 \\
\hline CP4.3 & 3.57 & 0.436 & 3.60 & \\
\hline CP4.4 & 3.74 & 0.517 & 3.75 & \\
\hline & & & & \\
\hline
\end{tabular}

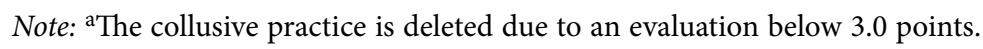

supplier, and academic institutions. More than $70 \%$ of them possessed six years of experience or above in the Chinese public construction sector. More than $80 \%$ of them occupied middle managerial positions or above in their institutions. Such a panel of respondents is believed to be sufficiently experienced to provide reliable evaluations on the collusive practices.

Although the sample size of this study is not large for the adoption of ANN approach, it can be justified by reviewing previous studies in which the ANN approach has been used for running data collected with comparable samples. For instance, Cheung et al. (2000) used 61 samples to build an ANN model to track the factors affecting the dispute resolution in construction projects in Hong Kong; Cheng et al. (2011) used 76 samples to develop a fuzzy hybrid neural network to improve the effectiveness of assessment on subcontractors' performance; Jha and Chockalingam (2011) used 76 samples to establish an ANN model for predicting schedule performance in construction projects of India; and Goh and Binte Sa'Adon (2015) used 40 samples to build an ANN model for exploring the cognitive factors 
affecting safety behaviour in the Singaporean construction industry. Since reliable findings have all been achieved in these studies, the sample size of this study should be able to satisfy the application of ANN approach in this study.

Considering the probability and severity of each collusive practice were evaluated simultaneously in the questionnaire, Formula (1) below was adopted to calculate the significance index of each collusive practice, as suggested by Ke et al. (2011):

$$
C P_{n i . j}=\sqrt{C P_{n p i . j} \times C P_{n s i . j}}
$$

where $C P_{n i . j}=$ the significance index of the $j$ th collusive practice under $i$ th collusive practice group, provided by the $n$th respondent; $C P_{n p i . j}=$ the probability assessment of the $j$ th collusive practice under $i$ th collusive practice group, provided by the $n$th respondent; and $C P_{n s i . j}=$ the severity assessment of the $j$ th collusive practice under $i$ th collusive practice group, provided by the $n$th respondent.

Table 4. Profile of questionnaire respondents

\begin{tabular}{|c|c|c|c|c|}
\hline $\begin{array}{l}\text { Personal } \\
\text { attribute }\end{array}$ & Category & $\begin{array}{l}\text { Number of } \\
\text { respondents }\end{array}$ & Percentage & $\begin{array}{l}\text { Cumulative } \\
\text { percentage }\end{array}$ \\
\hline \multirow{6}{*}{ Employer } & Client (CL) & 19 & 20 & 20 \\
\hline & Contractor $(\mathrm{CT})$ & 25 & 26 & 46 \\
\hline & Consultant (CS) & 18 & 19 & 65 \\
\hline & Designer (DE) & 15 & 15 & 80 \\
\hline & Supplier (SU) & 11 & 11 & 91 \\
\hline & Academia (AC) & 9 & 9 & 100 \\
\hline \multirow{3}{*}{ Position } & $\begin{array}{l}\text { Top managerial level (e.g., president, } \\
\text { general manager, chief director, professor) }\end{array}$ & 22 & 23 & 23 \\
\hline & $\begin{array}{l}\text { Middle managerial level (e.g., project } \\
\text { manager, department director, associate } \\
\text { professor) }\end{array}$ & 48 & 49 & 72 \\
\hline & $\begin{array}{l}\text { Professional (e.g., technician, quantity } \\
\text { surveyor) }\end{array}$ & 27 & 28 & 100 \\
\hline \multirow{4}{*}{$\begin{array}{l}\text { Years of } \\
\text { experience }\end{array}$} & $>20$ & 19 & 20 & 20 \\
\hline & $11-20$ & 28 & 29 & 49 \\
\hline & $6-10$ & 37 & 38 & 87 \\
\hline & $<5$ & 13 & 13 & 100 \\
\hline
\end{tabular}

Table 5 demonstrates the evaluations of 20 collusive practices. The top five collusive practices are misrepresentation of qualification certificates (CP2.2), loose site supervision (CP3.1), misusing prequalification requirements (CP1.1), fake tendering (CP1.4), and approval of the unnecessary change orders (CP3.4). Statistical tests were also conducted with the aid of IBM SPSS Statistics (2013). To test its reliability, the common tool Cronbach's alpha was adopted. In this study, the Cronbach's alpha was 0.935 , higher than the threshold of 0.7 (Hwang et al. 2015b), indicating the evaluations provided by the respondents are reliable. 


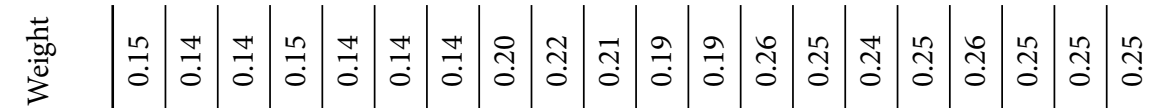

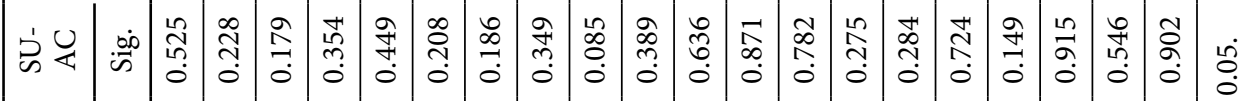

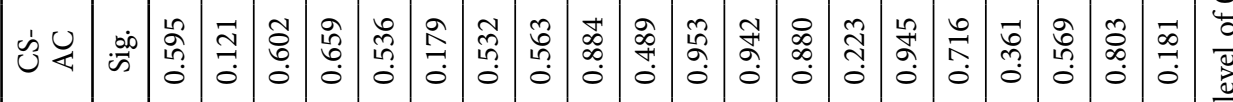

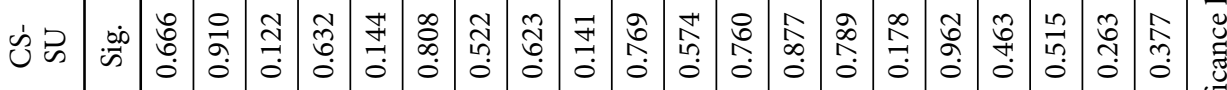

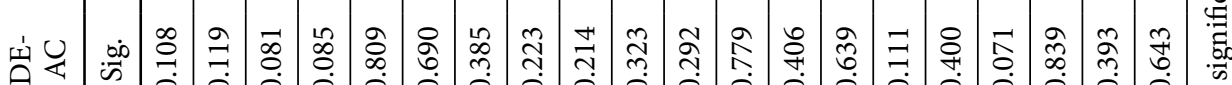

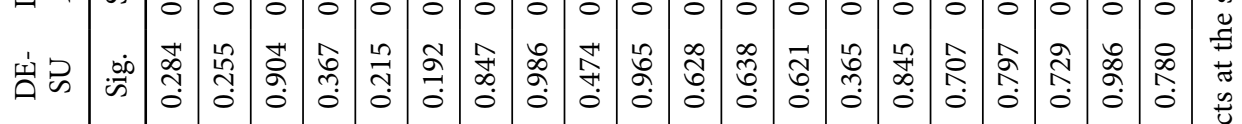

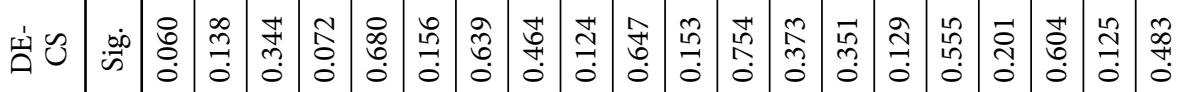
Uं山

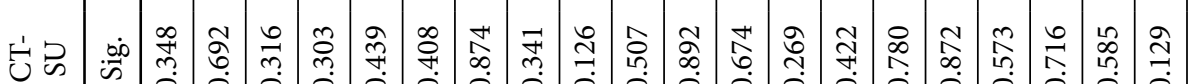

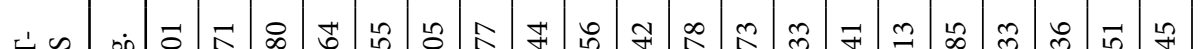

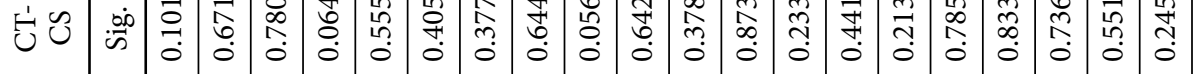

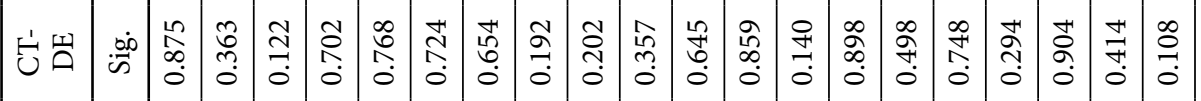
包

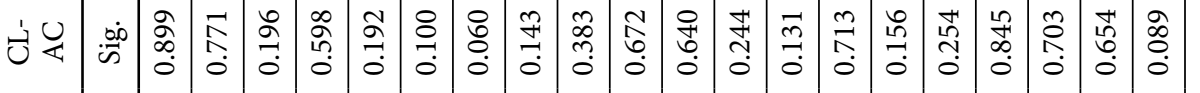

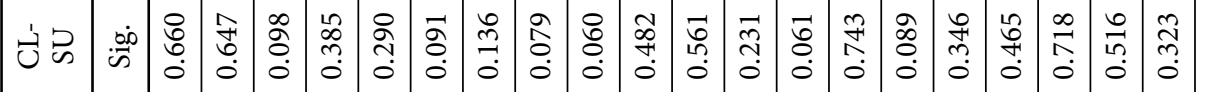

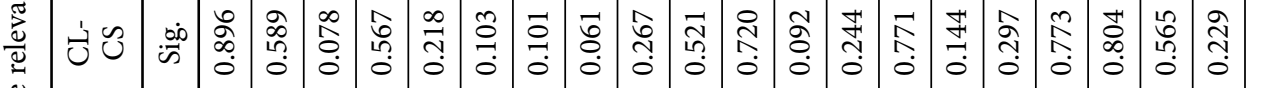

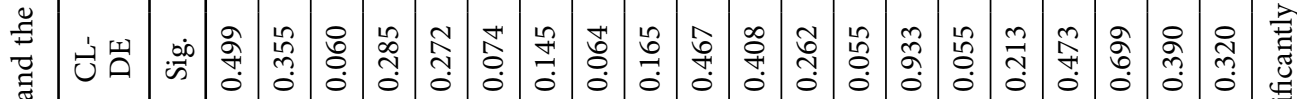
客

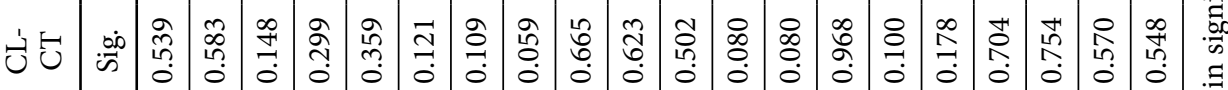

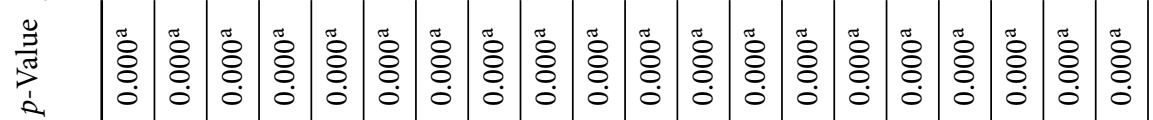

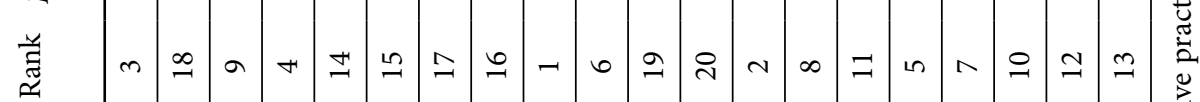

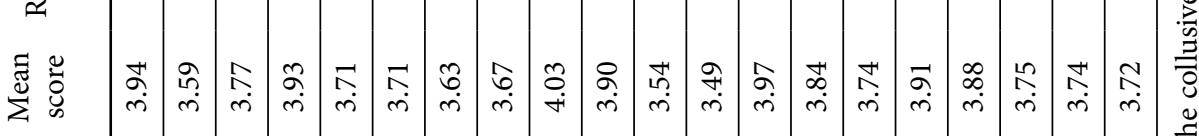

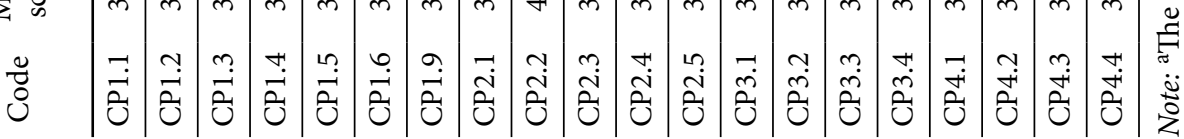
带 
To test whether each collusive practice has significant impact on Chinese construction projects, the one-sample t-test was carried out as suggested by Zhao et al. (2013a, 2013b, and 2016), with the test value of 3.00 at the significance level of 0.05 . The test results showed that the $p$-values of all the collusive practices were less than 0.05 (as shown in Table 5), suggesting that all the collusive practices have significant impact on Chinese construction projects, and thus were proper for further analysis.

To test if significant difference exists in respondents of different professional backgrounds (i.e. client, contractor, consultant, designer, supplier, and academia), the independent samples $t$-test was conducted, as suggested by Zhao et al. (2013c), Hwang et al. (2014, 2015a), and Gunduz and Yahya (2018). A confidence level of 95\% was adopted in this study. The test results in Table 5 show that significance values of all collusive practices are greater than 0.05 , indicating no significant differences among the respondents of different professional backgrounds.

\section{Development of ANN model}

\subsection{Calculations of inputs}

Considering that each collusive practice group was comprised of several different collusive practices, and that each collusive practice contributed to the group to different extents, weight for each specific collusive practice was calculated, using the Formula (2) as below:

$$
W_{i . j}=M S_{i . j} / \sum_{j=1}^{k} M S_{i . j},
$$

where $W_{i . j}=$ the weight of the $j$ th collusive practice under $i$ th collusive practice group, $M S_{i . j}=$ the mean score of the $j$ th collusive practice under $i$ th collusive practice group; and $k=$ the number of collusive practices under $i$ th group. The evaluation and weight for each specific collusive practice were shown in Table 5.

Subsequently, a collusive practice group index CPGI was calculated to represent the value of each collusive practice group, using the Formula (3) as below:

$$
C P I G_{n i}=\sum_{j=1}^{k} C P_{n i . j} \bullet W_{i . j},
$$

where $C P G I_{n i}=$ value of $i$ th collusive practice group, provided by the $n$th respondent, $C P_{n i . j}=$ value of $j$ th collusive practice under $i$ th collusive practice group, provided by the $n$th respondent, $W_{i . j}=$ the weight of the $j$ th collusive practice under $i$ th collusive practice group, calculated using Formula 2, and $k=$ the number of collusive practices under $i$ th group. The calculated CPGIs were used as inputs for the ANN model. In addition, data collected in the Part $\mathrm{C}$ of the questionnaire (i.e. respondents' perceptions of collusion risks in their evaluated projects), were utilized as outputs for the ANN model. 


\subsection{Training, validating, and testing of network}

Before dividing them into training, validating, and testing data sets, the data collected from 97 samples were randomized using NeuroSolutions (2015). Out of 97 samples, 87 samples were used to develop the model, in which 61 (70\%), 13 (15\%), and $13(15 \%)$ samples were utilized to train, validate, and test the network, respectively. Such a ratio follows the suggestions of Goh (1995), Boussabaine (1996), and Jha and Chockalingam (2011). The remaining ten samples were reserved to validate the model after it is developed, as suggested by Patel and Jha (2015a, 2015b). According to Berry and Linoff (1997), the quantity of hidden layer neurons should be no more than twofold of those in the input layer. Therefore, five trials were conducted with the different settings of hidden layer neurons, starting from four to eight. According to Patel and Jha (2015b), configuration of the network is determined according to the MSE and mean absolute percentage error (MAPE) generated in the processes of training, validating, and testing. According to Figures 1 and 2, which has plotted MSE and MAPE corresponding to the number of hidden neurons (from four to eight), the hidden layer with five neurons had the least MSE (0.0142) and MAPE (0.204) of all the alternatives. Therefore, the configuration 4-5-1 (number of inputs -number of hidden layer neurons -number of output) of the network was finalized for the model. Figure 3 depicts the configuration of the developed model.

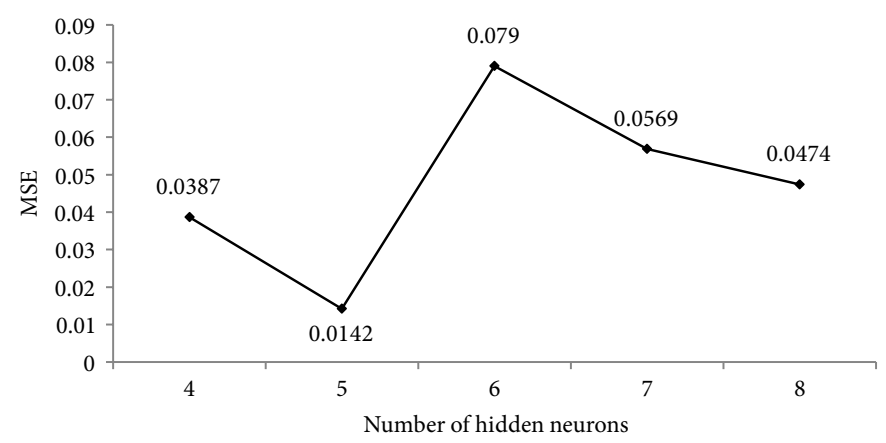

Figure 1. MSE versus the number of hidden neurons

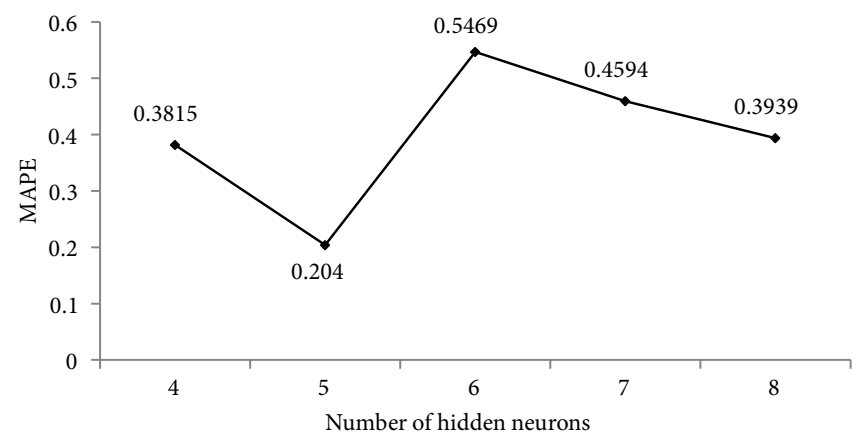

Figure 2. MAPE versus the number of hidden neurons 


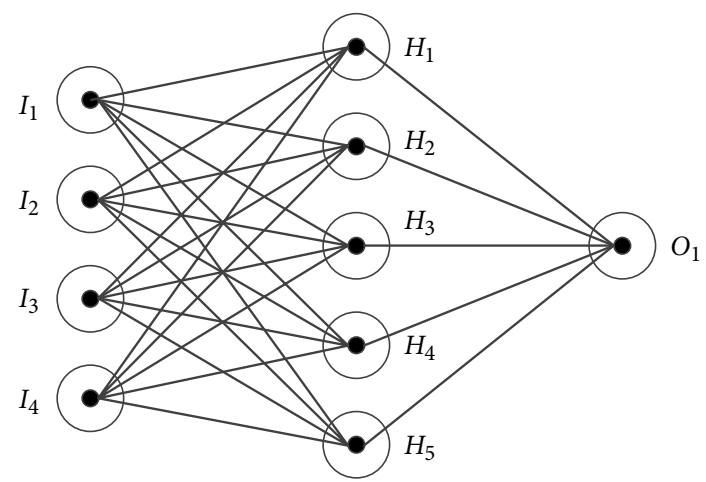

Figure 3. Configuration of the developed model

\subsection{Validation of the model}

To validate the developed model, absolute percentage deviation (APD) was calculated, as suggested by Patel and Jha (2015a, 2015b). APD is an indicator reflecting the prediction accuracy of a forecasting method in statistics, and could be computed by dividing the difference between actual and assessed results using the actual result. Based on the developed 4-5-1 ANN model, data of the remaining ten samples kept in reserve were input MATLAB NN Toolbox to calculate the assessed collusion risks. Based on the assessed and actual results, the APD of each sample was calculated and shown in Table 6. The obtained APDs ranged between $2.56 \%$ and $9.84 \%$. Although there is no unified due threshold on APD, Jha and his co-authors opined less than $10 \%$ an acceptable limit (Jha, Chockalingam 2011; Patel, Jha 2015a, 2015b). Thus, the assessment results of the developed model could be regarded as reliable.

Table 6. Comparison of actual and assessed results of collusion risk

\begin{tabular}{cccc}
\hline Sample & Actual result & Predicted result & APD (\%) \\
\hline 1 & 0.61 & 0.67 & 9.84 \\
\hline 2 & 0.90 & 0.83 & 7.78 \\
\hline 3 & 0.65 & 0.70 & 7.69 \\
\hline 4 & 0.65 & 0.69 & 6.15 \\
\hline 5 & 0.50 & 0.53 & 6.00 \\
\hline 6 & 0.45 & 0.49 & 8.89 \\
\hline 7 & 0.60 & 0.64 & 6.67 \\
\hline 8 & 0.78 & 0.76 & 2.56 \\
\hline 9 & 0.80 & 0.77 & 3.75 \\
\hline 10 & 0.65 & 0.68 & 4.62 \\
\hline
\end{tabular}




\section{Model application and discussion}

After the model was developed, a metro project in a provincial capital city in Central China was selected for model application. The project was selected because it is a major infrastructure project with an impressive estimated cost of CNY 100 billion (approximately US \$ 15.68 billion), which might provide a vast room for the ill-disposed practitioners to perform collusive practices. Before approaching to the project, the research team contacted the local construction authority and briefed them on the study in terms of research purpose, design, methodology, as well as the development of the model. Considering curbing collusive practices is one of its core missions, the local construction authority was ready to facilitate the model application. Four staff members of this institution that have been working on the project were provided the framework of collusive practices and requested to give their corresponding assessments. The collected assessments were then input the developed ANN model to assess the collusion risk in the project, with the aid of MATLAB NN Tool Box. The calculated results for the four staff members were 0.38, 0.43, 0.42, and 0.35 respectively, with an average result of 0.395 , indicating the project was not facing a severe collusion risk. The results were feedback to the staff members who believed that the assessed results were reliable as so far they had not detected collusive practices in this project or received any report in this regard. This was probably because the project was an important project to local society, and that the local authority directed considerable attention on it, and thus practitioners of the project would be quite cautious before deciding to conduct collusive practices. Moreover, the model application also implies that the developed model can be more helpful and meaningful if used by an independent third party or the construction authority as under such circumstances the inputs to the model wold be more reliable, and the assessment results would be more accurate accordingly.

\section{Conclusions}

Assessing collusion risk can definitely secure the projects' benefits from the insidious harm of collusion, because it can tell people to what extent the potential collusion exists in the project, and thus alert people proactively that corresponding anti-collusion measures should be formulated and implemented. This paper established a comprehensive framework of collusive practices in Chinese construction projects, which consists of 20 specific collusive practices related to all contracting parties. These collusive practices were further categorized into four groups, namely client related collusive practices in bidding, contractor related collusive practices in bidding, contractor related collusive practices in project construction, and supplier related collusive practices. Upon the established framework, this paper developed an ANN model to assess the collusion risks in Chinese construction projects. The model was applied in a real-life metro project, and the assessed results were proved to be reliable by its users.

Although the model was developed according to the context of China, this study is believed to be beneficial to the global construction community. First, the framework of collusive practices demonstrated in this study can provide the global construction contractors from developed countries with a better understanding of collusion in those emerging econ- 
omies like China. Second, the framework of collusive practices in this study can be utilized by some other developing countries to customize the list of collusive practices of their own, so that they can deal with their collusion problem more precisely. Third, the model developing strategy advocated in this study could be replicated in other countries, to facilitate the assessments of collusion in their construction projects. Further the findings of this study could be directed to the identification and evaluation of various anti-collusion strategies implemented in the construction industry. It would also be interesting to explore the attitudes and interactions among different stakeholders before they reach a collusive agreement.

\section{Funding}

This work was funded by the National Natural Science Foundation of China (Grant Nos. 71501142, 71172107 and 71390523/71395020), and the International Exchange Program for Graduate Students, Tongji University (Grant No. 201502014). Special thanks also go to the editor-in-charge and two anonymous reviewers for their constructive comments on earlier drafts.

\section{References}

Al-Sobiei, O. S.; Arditi, D.; Polat, G. 2005. Predicting the risk of contractor default in Saudi Arabia utilizing artificial neural network (ANN) and genetic algorithm (GA) techniques, Construction Management and Economics 23(4): 423-430. https://doi.org/10.1080/01446190500041578

Alutu, O. E. 2007. Unethical practices in Nigerian construction industry: prospective engineers' viewpoint, Journal of Professional Issues in Engineering Education and Practice 133(2): 84-88. https://doi.org/10.1061/(ASCE)1052-3928(2007)133:2(84)

Alutu, O. E.; Udhawuve, M. L. 2009. Unethical practices in Nigerian engineering industries: complications for project management, Journal of Management in Engineering 25(1): 40-43. https://doi.org/10.1061/(ASCE)0742-597X(2009)25:1(40)

Ameh, O. J.; Odusami, K. T. 2010. Professionals' ambivalence toward ethics in the Nigerian construction industry, Journal of Professional Issues in Engineering Education and Practice 136(1): 9-16. https://doi.org/10.1061/(ASCE)1052-3928(2010)136:1(9)

Ameyaw, E. E.; Hu, Y.; Shan, M.; Chan, A. P. C.; Le, Y. 2016. Application of Delphi method in construction engineering and management research: a quantitative perspective, Journal of Civil Engineering and Management 22(8): 991-1000. https://doi.org/10.3846/13923730.2014.945953

Ballesteros-Pérez, P.; González-Cruz, M. C.; Cañavate-Grimal, A.; Pellicer, E. 2013. Detecting abnormal and collusive bids in capped tendering, Automation in Construction 31(0): 215-229. https://doi.org/10.1016/j.autcon.2012.11.036

Berry, M. J. A.; Linoff, G. 1997. Data mining techniques. New York: Wiley.

Boussabaine, A. H. 1996. The use of artificial neural networks in construction management: a review, Construction Management and Economics 14(5): 427-436. https://doi.org/10.1080/014461996373296

Bowen, P. A.; Edwards, P. J.; Cattell, K. 2012. Corruption in the South African construction industry: a thematic analysis of verbatim comments from survey participants, Construction Management and Economics 30(10): 885-901. https://doi.org/10.1080/01446193.2012.711909

Bowen, P.; Akintoye, A.; Pearl, R.; Edwards, P. J. 2007a. Ethical behaviour in the South African construction industry, Construction Management and Economics 25(6): 631-648.

https://doi.org/10.1080/01446190701225707 
Bowen, P.; Pearl, R.; Akintoye, A. 2007b. Professional ethics in the South African construction industry, Building Research and Information 35(2): 189-205.

https://doi.org/10.1080/09613210600980267

Brown, J.; Loosemore, M. 2015. Behavioural factors influencing corrupt action in the Australian construction industry, Engineering, Construction and Architectural Management 22(4): 372-389. https://doi.org/10.1108/ECAM-03-2015-0034

Carr, R.; Maloney, W. 1983. Basic research needs in construction engineering, Journal of Construction Engineering and Management 109(2): 181-189. https://doi.org/10.1061/(ASCE)0733-9364(1983)109:2(181)

Cheng, M. Y.; Tsai, H. C.; Sudjono, E. 2011. Evaluating subcontractor performance using evolutionary fuzzy hybrid neural network, International Journal of Project Management 29(3): 349-356. https://doi.org/10.1016/j.ijproman.2010.03.005

Cheng, M. Y.; Tsai, H. C.; Sudjono, E. 2012. Evolutionary fuzzy hybrid neural network for dynamic project success assessment in construction industry, Automation in Construction 21(1): 46-51. https://doi.org/10.1016/j.autcon.2011.05.011

Cheng, M. Y.; Wu, Y. W.; Wu, C. F. 2010. Project success prediction using an evolutionary support vector machine inference model, Automation in Construction 19(3): 302-307. https://doi.org/10.1016/j.autcon.2009.12.003

Cheung, S. O.; Tam, C. M.; Harris, F. C. 2000. Project Dispute Resolution Satisfaction classification through neural network, Journal of Management in Engineering 16(1): 70-79. https://doi.org/10.1061/(ASCE)0742-597X(2000)16:1(70)

Cheung, S. O.; Wong, P. S. P.; Fung, A. S. Y.; Coffey, W. V. 2006. Predicting project performance through neural networks, International Journal of Project Management 24(3): 207-215. https://doi.org/10.1016/j.ijproman.2005.08.001

Chotibhongs, R.; Arditi, D. 2012a. Analysis of collusive bidding behaviour, Construction Management and Economics 30(3): 221-231. https://doi.org/10.1080/01446193.2012.661443

Chotibhongs, R.; Arditi, D. 2012b. Detection of collusive behavior, Journal of Construction Engineering and Management 138(11): 1251-1258. https://doi.org/10.1061/(ASCE)CO.1943-7862.0000542

de Jong, M.; Henry, W. P.;S tansbury, N. 2009. Eliminating corruption in our engineering/construction industry, Leadership and Management in Engineering 9(3): 105-111. https://doi.org/10.1061/(ASCE)1532-6748(2009)9:3(105)

Demuth, D.; Beale, M. 2000. Neural network toolbox for use with MATLAB. Natick, Massachusetts: Math Works.

Dikmen, I.; Birgonul, M. T.; Kiziltas, S. 2005. Prediction of organizational effectiveness in construction companies, Journal of Construction Engineering and Management 131(2): 252-261. https://doi.org/10.1061/(ASCE)0733-9364(2005)131:2(252)

Dorée, A. G. 2004. Collusion in the Dutch construction industry: an industrial organization perspective, Building Research and Information 32(2): 146-156. https://doi.org/10.1080/0961321032000172382

Georgy, M. E.; Chang, L. M.; Zhang, L. 2005. Prediction of engineering performance: a neurofuzzy approach, Journal of Construction Engineering and Management 131(5): 548-557. https://doi.org/10.1061/(ASCE)0733-9364(2005)131:5(548)

Goh, A. T. C. 1995. Back-propagation neural networks for modeling complex systems, Artificial Intelligence in Engineering 9(3): 143-151. https://doi.org/10.1016/0954-1810(94)00011-S

Goh, Y. M.; Binte Sa’Adon, N. F. 2015. Cognitive factors influencing safety behavior at height: a multimethod exploratory study, Journal of Construction Engineering and Management 141(6): 04015003. https://doi.org/10.1061/(ASCE)CO.1943-7862.0000972

Goh, Y. M.; Chua, D. 2013. Neural network analysis of construction safety management systems: a case study in Singapore, Construction Management and Economics 31(5): 460-470. https://doi.org/10.1080/01446193.2013.797095 
Gunduz, M.; Önder, O. 2013. Corruption and internal Fraud in the Turkish construction industry, Science and Engineering Ethics 19(2): 505-528. https://doi.org/10.1007/s11948-012-9356-9

Gunduz, M.; Yahya, A. M. A. 2018. Analysis of project success factors in construction industry, Technological and Economic Development of Economy, 24(1): 67-80. https://doi.org/10.3846/20294913.2015.1074129

Hallowell, M.; Gambatese, J. 2009. Qualitative research: application of the Delphi method to CEM research, Journal of Construction Engineering and Management 136(1): 99-107. https://doi.org/10.1061/(ASCE)CO.1943-7862.0000137

Hartley, R. 2009. Fighting corruption in the Australian construction industry: the national code of practice, Leadership and Management in Engineering 9(3): 131-135. https://doi.org/10.1061/(ASCE)1532-6748(2009)9:3(131)

Hon, C. K.; Chan, A. P.; Yam, M. C. 2012. Empirical study to investigate the difficulties of implementing safety practices in the repair and maintenance sector in Hong Kong, Journal of Construction Engineering and Management 138(7): 877-884. https://doi.org/10.1061/(ASCE)CO.1943-7862.0000497

Hu, Y.; Chan, A.; Le, Y.; Jin, R. 2015. From construction megaproject management to complex project management: a bibliographic analysis, Journal of Management in Engineering 31(4). https://doi.org/10.1061/(ASCE)ME.1943-5479.0000254

Hussain, M. A.; Aroua, M. K.; Yin, C. Y.; Rahman, R. A.; Ramli, N. A. 2010. Hybrid neural network for prediction of CO 2 solubility in monoethanolamine and diethanolamine solutions, Korean Journal of Chemical Engineering 27(6): 1864-1867. https://doi.org/10.1007/s11814-010-0270-z

Hwang, B. G.; Zhao, X.; Yu, G. S. 2016. Risk identification and allocation in underground rail construction joint ventures: contractors' perspective, Journal of Civil Engineering and Management 22(6): 758-767. https://doi.org/10.3846/13923730.2014.914095

Hwang, B. G.; Zhao, X.; Ong, S. 2015a. Value management in Singaporean building projects: implementation status, critical success factors, and risk factors, Journal of Management in Engineering 31(6): 04014094. https://doi.org/10.1061/(ASCE)ME.1943-5479.0000342

Hwang, B. G.; Zhao, X.; See, Y. L.; Zhong, Y. 2015b. Addressing risks in green retrofit projects: the case of Singapore, Project Management Journal 46(4): 76-89. https://doi.org/10.1002/pmj.21512

Hwang, B. G.; Zhao, X.; Do, T. H. V. 2014. Influence of trade-level coordination problems on project productivity, Project Management Journal 45(5): 5-14. https://doi.org/10.1002/pmj.21445

Hwang, B. G.; Ng, H. B. 2015. Project network management: risks and contributors from the viewpoint of contractors and sub-contractors, Technological and Economic Development of Economy 22(4): 631-648. https://doi.org/10.3846/20294913.2015.1067847

IBM SPSS Statistics. 2013. SPSS for Windows. [Software] Version 22. New York: IBM SPSS Statistics.

Ika, L. A. 2012. Project management for development in Africa: why projects are failing and what can be done about it, Project Management Journal 43(4): 27-41. https://doi.org/10.1002/pmj.21281

Jamieson, S. 2004. Likert scales: how to (ab)use them, Medical Education 38(12): 1217-1218. https://doi.org/10.1111/j.1365-2929.2004.02012.x

Jha, K. N.; Chockalingam, C. T. 2011. Prediction of schedule performance of Indian construction projects using an artificial neural network, Construction Management and Economics 29(9): 901-911. https://doi.org/10.1080/01446193.2011.608691

Jin, X. H.; Zhang, G. 2011. Modelling optimal risk allocation in PPP projects using artificial neural networks, International Journal of Project Management 29(5): 591-603. https://doi.org/10.1016/j.ijproman.2010.07.011

Ke, Y.; Wang, S.; Chan, A. P.; Cheung, E. 2011. Understanding the risks in China's PPP projects: ranking of their probability and consequence, Engineering, Construction and Architectural Management 18(5): 481-496. https://doi.org/10.1108/09699981111165176 
Ko, C. H.; Cheng, M. Y.; Wu, T. K. 2007. Evaluating sub-contractors performance using EFNIM, Automation in Construction 16(4): 525-530. https://doi.org/10.1016/j.autcon.2006.09.005

Ko, C. H.; Cheng, M. Y. 2007. Dynamic prediction of project success using artificial intelligence, Journal of Construction Engineering and Management 133(4): 316-324. https://doi.org/10.1016/j.autcon.2006.09.005

Le, Y.; Shan, M.; Chan, A. P. C.; Hu, Y. 2014a. Investigating the causal relationships between causes of and vulnerabilities to corruption in the Chinese public construction sector, Journal of Construction Engineering and Management 140(9): 05014007. https://doi.org/10.1061/(ASCE)CO.1943-7862.0000886

Le, Y.; Shan, M.; Chan, A. P. C.; Hu, Y. 2014b. Overview of corruption research in construction, Journal of Management in Engineering 30(4): 02514001. https://doi.org/10.1061/(ASCE)ME.1943-5479.0000300

Le, Y.; Shan, M. 2014. Research trend of collusion in top construction journals, in 17th International Symposium on Advancement of Construction Management and Real Estate, 17-18 November 2012, Shenzhen, China. https://doi.org/10.1007/978-3-642-35548-6_115

Lo, W.; Krizek, R. J.; Hadavi, A. 1999. Effects of high prequalification requirements, Construction Management and Economics 17(5): 603-612. https://doi.org/10.1080/014461999371213

Molenaar, K. R. 2005. Programmatic cost risk analysis for highway megaprojects, Journal of Construction Engineering and Management 131(3): 343-353. https://doi.org/10.1061/(ASCE)0733-9364(2005)131:3(343)

Moselhi, O.; Hegazy, T.; Fazio, P. 1991. Neural networks as tools in construction, Journal of Construction Engineering and Management 117(4): 606-625. https://doi.org/10.1061/(ASCE)0733-9364(1991)117:4(606)

National Bureau of Corruption Prevention of China. 2011. Analysis on typical corruption cases in the construction sector and instructions for corruption prevention. Beijing, China: Fangzheng Press of China.

NeuroSolutions. 2015. NeuroSolutions for Windows. [Software] Version 7. Gainesville, FL: NeuroSolutions.

OECD. 2009. Guidelines for Fighting Bid Rigging in Public Procurement [online], [cited 10 December 2015]. Available from Internet: http://www.oecd.org/daf/competition/cartels/42851044.pdf

OECD. 2012. Recommendation of the OECD Council on Fighting Bid Rigging in Public Procurement [online], [cited 10 December 2015]. Available from Internet: http://www.oecd.org/daf/competition/ RecommendationOnFightingBidRigging2012.pdf.

Patel, D. A.; Jha, K. N. 2015a. Neural network model for the prediction of safe work behavior in construction projects, Journal of Construction Engineering and Management 141(1): 04014066. https://doi.org/10.1061/(ASCE)CO.1943-7862.0000922

Patel, D.; Jha, K. 2015b. Neural Network Approach for safety climate prediction, Journal of Management in Engineering 31(6): 05014027. https://doi.org/10.1061/(ASCE)ME.1943-5479.0000348

Priemus, H. 2004. Dutch contracting fraud and governance issues, Building Research \& Information 32(4): 306-312. https://doi.org/10.1080/0961321042000221089

Ray, R. S.; Horinbrook, J.; Skitmore, M.; Zarkada-Fraser, A. 1999. Ethics in tendering: a survey of Australian opinion and practice, Construction Management and Economics 17(2): 139-153. https://doi.org/10.1080/014461999371646

Rumelhart, D. E.; Widrow, B.; Lehr, M. A. 1994. Basic ideas in neural networks, Communications of the ACM 37(3): 87-92. https://doi.org/10.1145/175247.175256

Samarasinghe, S. 2007. Neural networks for applied sciences and engineering. Boca Raton: Taylor \& Francis.

Shan, M.; Chan, A. P. C.; Le, Y.; Hu, Y. 2015a. Investigating the effectiveness of response strategies for vulnerabilities to corruption in the Chinese public construction sector, Science and Engineering Ethics 21(3): 683-705. https://doi.org/10.1007/s11948-014-9560-x 
Shan, M.; Chan, A. P. C.; Le, Y.; Xia, B.; Hu, Y. 2015b. Measuring corruption in public construction projects in China, Journal of Professional Issues in Engineering Education and Practice 141(4): 05015001. https://doi.org/10.1061/(ASCE)EI.1943-5541.0000241

Shan, M.; Chan, A. P. C.; Le, Y.; Hu, Y.; Xia, B. 2017. Understanding collusive practices in Chinese construction projects, Journal of Professional Issues in Engineering Education and Practice 143(3). https://doi.org/10.1061/(ASCE)EI.1943-5541.0000314

Shen, L. Y.; Wu, G. W. C.; Ng, C. S. K. 2001. Risk assessment for construction joint ventures in China, Journal of Construction Engineering and Management 127(1): 76-81. https://doi.org/10.1061/(ASCE)0733-9364(2001)127:1(76)

Sichombo, B.; Muya, M.; Shakantu, W.; Kaliba, C. 2009. The need for technical auditing in the Zambian construction industry, International Journal of Project Management 27(8): 821-832. https://doi.org/10.1016/j.ijproman.2009.02.001

Sohail, M.; Cavill, S. 2008. Accountability to prevent corruption in construction projects, Journal of Construction Engineering and Management 134(9): 729-738. https://doi.org/10.1061/(ASCE)0733-9364(2008)134:9(729)

Tabish, S.; Jha, K. N. 2011. Analyses and evaluation of irregularities in public procurement in India, Construction Management and Economics 29(3): 261-274. https://doi.org/10.1080/01446193.2010.549138

The National People's Congress of People's Republic of China. 1999. Bidding Law of People's Republic of China [online] [cited 19 August 2014]. Available from Internet: http://www.npc.gov.cn/wxzl/ gongbao/2000-12/05/content_5004749.htm.

Vee, C.; Skitmore, C. 2003. Professional ethics in the construction industry, Engineering, Construction and Architectural Management 10(2): 117-127. https://doi.org/10.1108/09699980310466596

Wang, J.; Liu, J.; Liao, Z.; Tang, P. 2009. Identification of key liability risks of supervision engineers in China, Construction Management and Economics 27(12): 1157-1173. http://dx.doi.org/10.1080/01446190903222395

Wang, Y. R.; Gibson Jr., G. E. 2010. A study of preproject planning and project success using ANNs and regression models, Automation in Construction 19(3): 341-346. https://doi.org/10.1016/j.autcon.2009.12.007

Xia, B.; Chan, A. P. C. 2012a. Measuring complexity for building projects: a Delphi study, Engineering, Construction and Architectural Management 19(1): 7-24. https://doi.org/10.1108/09699981211192544

Xia, B.; Chan, A. P. C. 2012b. Identification of selection criteria for operational variations of the designbuild system: a Delphi study in China, Journal of Civil Engineering and Management 18(2): 173-183. https://doi.org/10.3846/13923730.2012.657417

Xinhua Net. 2014. Irregularities in project biddings of Three Gorges Project: Nepotism, and waste of public money [online], [cited 9 May 2014]. Available from Internet: http://news.xinhuanet.com/ finance/2014-02/19/c_126159860.htm

Xinhua Net. 2015. How many inside stories of bidding have been refracted by huge kickbacks in small projects? [online], [cited 23 September 2015]. Available from Internet: http://news.xinhuanet.com/ fortune/2015-09/19/c_1116615043.htm

Yi, W.; Chan, A. 2014. Critical review of labor productivity research in construction journals, Journal of Management in Engineering 30(2): 214-225. https://doi.org/10.1061/(ASCE)ME.1943-5479.0000194

Zarkada-Fraser, A. 2000. A classification of factors influencing participating in collusive tendering agreements, Journal of Business Ethics 23(3): 269-282. https://doi.org/10.1023/A:1006210308373

Zarkada-Fraser, A.; Skitmore, M. 2000. Decisions with moral content: collusion, Construction Management \& Economics 18(1): 101-111. https://doi.org/10.1080/014461900370997 
Zhang, B.; Le, Y.; Xia, B.; Skitmore, M. 2017. Causes of business-to-government corruption in the tendering process in China, Journal of Management in Engineering 33(2). https://doi.org/10.1061/(ASCE)ME.1943-5479.0000479

Zhang, G.; Patuwo, E.; Hu, M. Y. 1998. Forecasting with artificial neural networks: the state of the art, International Journal of Forecasting 14(1): 35-62. https://doi.org/10.1016/S0169-2070(97)00044-7

Zhao, X.; Hwang, B. G.; Low, S. P. 2013a. Developing fuzzy enterprise risk management maturity model for construction firms, Journal of Construction Engineering and Management 139(9): 1179-1189. https://doi.org/10.1061/(ASCE)CO.1943-7862.0000712

Zhao, X.; Hwang, B. G.; Low, S. P. 2013b. Critical success factors for enterprise risk management in Chinese construction companies, Construction Management and Economics 31(12): 1199-1214. https://doi.org/10.1080/01446193.2013.867521

Zhao, X.; Hwang, B.; Yu, G. S. 2013c. Identifying the critical risks in underground rail international construction joint ventures: case study of Singapore, International Journal of Project Management 31(4): 554-566. https://doi.org/10.1016/j.ijproman.2012.10.014

Zhao, X.; Hwang, B. G.; Lee, H. N. 2016. Identifying critical leadership styles of project managers for green building projects, International Journal of Construction Management 16(2): 150-160. https://doi.org/10.1080/15623599.2015.1130602

Zou, P. X. 2006. Strategies for minimizing corruption in the construction industry in China, Journal of Construction in Developing Countries 11(2): 15-29.

Zou, P. X.; Zhang, G. 2009. Comparative study on the perception of construction safety risks in China and Australia, Journal of Construction Engineering and Management 135(7): 620-627.

https://doi.org/10.1061/(ASCE)CO.1943-7862.0000019 